\title{
THE FOOD PYRAMID ADAPTED TO PHYSICALLY ACTIVE ADOLESCENTS AS A NUTRITION EDUCATION TOOL'
}

\author{
MS. CAMILA BRANDÃO GONÇALVES \\ Programa de Pós-gradação em Educação Física, Faculdade \\ de Educação Física, Universidade de Brasília \\ (Brasília - Distrito Federal - Brasil) \\ E-mail: camilabg I@hotmail.com
}

\author{
DRA. JÚLIA APARECIDA DEVIDÉ NOGUEIRA \\ Programa de Pós-gradação em Educação Física, Faculdade \\ de Educação Física, Universidade de Brasília \\ (Brasília - Distrito Federal - Brasil) \\ E-mail: julianogueira@unb.br
}

\section{DRA. TERESA HELENA MACEDO DA COSTA \\ Departamento de Nutrição, Faculdade de Ciências da Saúde, Universidade de Brasília (Brasília - Distrito Federal - Brasil) \\ E-mail: hdacosta@unb.br}

\begin{abstract}
This study aimed to assess the understanding of the Food Pyramid Adapted to Physically Active Adolescents as an educational tool to improve nutrition knowledge. Adolescents engaged in sport training responded to a nutrition knowledge questionnaire before and after the intervention. The pyramid intervention group received the printed educational material, and the broad intervention group received the printed material followed by a lecture. As a result, mean initial nutrition knowledge was average (59.9 \pm 18 points), increasing $(p<0.001)$ after the intervention (69.1 \pm 20 points) without significant difference between interventions. In conclusion, adolescents' nutrition knowledge improved, even with the use of the Food Pyramid alone, indicating its use to promote nutritional knowledge.

KEYWORDS: Adolescence; Sports; Eating Habits; Food Groups.

I. The project received partial funding from Embrapa Café (project no 19.2004.398.0 I, protocol n 2004.009.0 I) and Conselho Nacional de Desenvolvimento Científico e Tecnológico (CNPq; research productivity bursaries n 302520/2008-2); and a translation grant from the Graduate Rectory, University of Brasilia. There was no conflict of interest on the realization of the study.
\end{abstract}




\section{INTRODUCTION}

Adolescence is a period of growth, maturation and rapid physiological and psychological changes (ALBERGA et al., 20 I 2). It is also a critical period for behavioral changes that might be sustained throughout the lifespan: physical activity and sports participation decline during adolescence, especially in girls (ALLISON et al., 2007); and adolescents are vulnerable to poor nutritional status resulting from inadequate food intake and unhealthy dietary practices (DWYER et al., 200I). These changes during adolescence require the attention of parents and professionals that work with adolescents to promote health and prevent the onset of obesity and its associated diseases (REES et al., 1999; ALBERGA et al., 2012).

In this regard, regular physical activity such as sports participation (AMERICAN ACADEMY OF PEDIATRICS et al., 2006) and healthy eating (REES et al., 1999) are systematically encouraged as part of healthy living (WORLD HEALTH ORGANIZATION, 2004). However, on top of the specific nutritional requirements arising from inherent biological changes (REES et al., I999; ALBERGA et al., 20 I 2), adolescents engaged in sports participation have increased energy and carbohydrate requirements, which may further prevent them from obtaining nutritional balance (INSTITUTE OF MEDICINE, 2002; AMERICAN HEART ASSOCIATION, 2006).

Nutrition education is an essential tool to promote healthy eating habits (PÉREZ-RODRIGO; ARANCETA, 200 I; WORSLEY, 2002; PRELIP, 20I I). When nutrition education is used as an intervention strategy, there is an improvement in nutrition knowledge, attitudes and eating behavior (PÉREZ-RODRIGO; ARANCETA, $200 \mathrm{I}$; PRELIP, $20 \mathrm{I}$ I). Although the change in eating behavior is part of a broader perspective of adherence, which involves the environment and individuals' interactions, correct notions of diet and nutrition continue to play a key role in the adoption of healthy habits (WORSLEY, 2002).

There are tools that provide guidance on food intake, are widely accepted and well understood and, for this reason, are known by the general population (PHILIPPI et al., 1999; UNITED STATE, 20 I2). The food pyramid is a visual guide used to teach the general population and athletes how to adequately select foods (PHILIPPI et al., I 999; NOGUEIRA; DA COSTA, 2004; METTLER; MANNHART; COLOMBANI, 2009). In this context, the Food Pyramid Adapted to Physically Active Adolescents showed in Figure I (DA COSTA et al., 20I2) was developed from the Food Pyramid adapted to the Brazilian population (PHILIPPI et al., 1999), as a tool to provide guidance on how to obtain a balanced diet.

This tool considered the increased requirements for liquids, energy ( I,500 to $3,500 \mathrm{Kcal} / \mathrm{d}$ ) and nutrients (increase in the number of servings of bread and cereals, 
fruits, vegetables, milk, meat and legumes) intake of physically active adolescents. In addition, it was designed in a colorful and attractive way and included descriptions of adequate eating habits (PHILIPPI et al., 1999; DA COSTA et al., 20 I2; UNITED STATE, 20 I 2). In 201 I, the United Sates Department of Agriculture (USDA) introduced a new food guide for the American population, using a circle to characterize a plate of food (USDA, 20I2). In the case of individuals engaged in sports, the pyramidal shape is consistent with some training proposals and can be better understood (FLECK; KRAEMER, 2004; METTLER; MANNHART; COLOMBANI, 2009).

Thus, the present study aimed to evaluate the understanding of the Food Pyramid Adapted to Physically Active Adolescents as a simple, inexpensive, self-explanatory and easily applicable nutrition education tool.

FOOD PYRAMID ADAPTED TO PHYSICALLY ACTIVE ADOLESCENTS

The Food Pyramid is a guide that helps you choose the foods that must make up your daily diet. The ranges of servings indicated in the food pyramid groups provide between 1,500 and $3,500 \mathrm{Kcal} /$ day. The serving equivalents show examples of foods that correspond to a serving of each group in the pyramid.

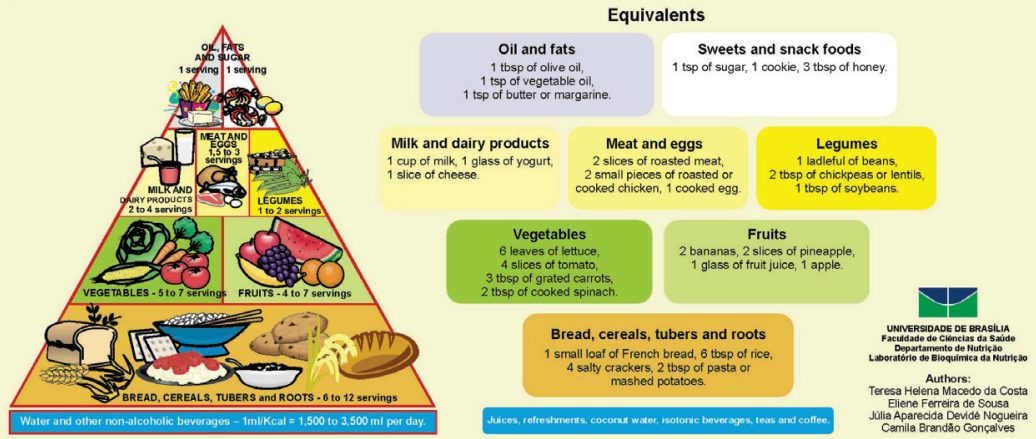

\section{General recommendations}

\section{Be creative: eat a great variety of foods}

- Have at least four meals a day. Do not skip any of the three main meals (breakfast, lunch and dinner). Meal times can be adjusted to training times

- Chew your food well.

- Do not exercise while fasting. Before training, give preference to foods from the pyramid base: bread and cereals, fruits and vegetables.

- Athletes usually consume adequate amounts of energy, but this does not guarantee a sufficient supply of vitamins and minerals mainly present in fruits, vegetables and milk.

- Give preference to fruits and vegetables, always including them in your meals.

- Avoid sodas.

- Give preference to baked snack foods.

- Avoid fried foods.
- Eat sweets right after training/competitions.Drink liquids, especially water, between meals.

- Follow the liquid intake recommended by the Pyramid. While training, do not wait until you feel thirsty to drink water. Drink a glass $(200 \mathrm{ml})$ after every 20 minutes of vigorous activity, especially during hot weather.

- Vary your diet and foods from each Pyramid Guide group in your daily meals and during the week. You will not need to take any supplements if you vary your diet.

\section{www.unb.br/fs/adolescente}

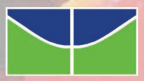

UNIVERSIDADE DE BRASÍLIA School of Health Sciences Department of Nutrition Laboratory of Nutritional Biochemistry

Figure I. Food pyramid adapted to physically active adolescents. 
The present study had an analytical, longitudinal and intervention design and was approved by the National Research Ethics Committee, registered under number 7364/2003. A search in the Brasília-Brazil phone book identified a total of 32 sports clubs that were situated in the Plano Piloto, an area that houses the upper-middle socio-economic class. A non-probabilistic random selection to draw 4 sports clubs out of the 32 available was carried out, followed by a telephone call to confirm if they would agree to participate in the study and if they fulfilled the following criteria, previously defined for inclusion in the study: a) work with adolescents who were between 12 and 15 years of age until the day of the interview; b) provide three or more hours of training per week; c) have technical guidance; and d) participate in any level of competition.

All adolescents from the four sports clubs selected were invited and agreed to participate $(n=58)$ and each adolescent and their responsible adult signed an informed consent form to participate in the study. Exclusion criteria were: a) the adolescent being ill (or using a cast) and b) pregnant girls. No adolescents met the exclusion criteria and, consequently, all of them were included.

In stage I, adolescents responded to the following questionnaires: socio-demographic; sexual maturation; daily and physical activities; nutrition knowledge questionnaire (NKQ); and three non-consecutive 24-hour food recall questionnaires; applied by trained interviewees. Next, anthropometric measurements (weight, height, and triceps and subscapular skinfolds) were assessed by a single evaluator, according to the Anthropometric Standardization Reference Manual (LOHMAN; ROCHE; MARTORELL, 1988). Data collection was performed in the training location, during the usual time of activities.

The questionnaires applied in the present study were adapted from instruments used in previous research with adolescents (NOGUEIRA; DA COSTA, 2009) and tested with a pilot study. Sexual maturation was identified through self-reporting the presence of menarche in girls and the presence of thick and abundant underarm hair in boys. The presence of underarm hair in boys is a practical non-intrusive methodology used to identify the presence or absence of sexual maturation in adolescents, when a complete physical exam is not appropriate (NOGUEIRA; DA COSTA, 2009).

The daily activities questionnaire quantified time spent sleeping, attending classes, watching television, playing video games or using a computer, in which specific questions about physical activities and training were included. Information about the type, duration and intensity of physical activities was quantified with the questionnaire adapted from the short version of the International Physical Activity Questionnaire (IPAQ, 2009). 
The NKQ was adapted from studies conducted with Brazilians (LIMA; MONTEIRO; PAES, 1985; TRICHES; GIUGLIANI, 2005), to which three specific questions about the food pyramid were added. Questions were scored according to the level of difficulty, with the question that directly analyzed knowledge about the food pyramid recommendation having a higher score. Adolescents completed the questionnaires blind to the score of each question. Data on the food recall questionnaires were input into the NUTRISURVEY software (2005 version), grouped into servings of food groups, and subsequently compared with the intakes recommended by the Food Pyramid Adapted to Physically Active Adolescents (DA COSTA et. al., 2012).

When stage I finished, sports teams were randomly divided into two intervention groups, mindful of different groups not being in contact with one another. Because sport teams have a different number of players, this resulted in a different number of subjects in each intervention type. The Broad intervention group (Bl; $\mathrm{n}=24$ ) received the printed educational material about the Food Pyramid Adapted to Physically Active Adolescents (FIGURE I) in return for their participation in the study and attended a ten-minute lecture on this material, the pyramid food groups and the recommendations included on the back of the material. Then, adolescents were encouraged to ask their questions, although there were few questions, which lasted less than five minutes in all. The Pyramid intervention group (PI; $n=34$ ) received only the printed educational material on the Food Pyramid Adapted to Physically Active Adolescents (FIGURE I) in return for their participation in the study, without any additional explanations about the material.

One month after the intervention, in stage 2 , adolescents responded to the questionnaires again, in a manner similar to that described in stage I. In stage 2, however, there was no food recall questionnaire and there was a loss of five individuals, who stopped participating in the regular training activities, did not answer the telephone calls, and consequently did not respond to the questionnaires.

The data collected were analyzed to search for inconsistencies, which were not found, and subsequently tabulated. The socioeconomic level was categorized according to the Brazilian economic classification criteria recommended by the Associação Brasileira de Empresas de Pesquisa (ABEP - Brazilian Association of Market Research Companies), which includes the description of household consumer goods and the head of the household's level of formal education (ABEP, 2003). Body weight and height were used to calculate the body mass index (BMI), which was subsequently categorized according to the criteria established by Cole et al. (2000) e Cole; Katherine (2007). Skinfolds were used to estimate the percentage of body fat (\%BF), in accordance with the formulas developed by Siri (1956) and Boileau, 
Lohman and Slaughter (1985). Data on daily activities and physical activities were used to calculate the physical activity level (PAL), according to the FAO/WHO/UNU (200 I), and this level was classified according to the Institute of Medicine's (IOM) criteria (INSTITUTE OF MEDICINE, 2002).

The level of nutrition knowledge was analyzed from the sum of points obtained from the NKQ, which enabled adolescents to score between zero and 100 points. The improvement in the level of nutrition knowledge was taken into consideration when the sum of points in stage 2 was higher than that in stage 1 .

The statistical analysis was performed using the SPSS software program (version 13). The normality of distribution was tested with the Kolmogorov-Smirnov test. Continuous variables were expressed as central tendency measure (mean) and their dispersion as standard deviation (SD), and minimum (Min.) and maximum (Max.) values. The frequencies of distribution were used for categorical variables. Pearson's correlation was used to observe a linear association of the PAL values and the total number of hours spent on sedentary activities with the total number of points obtained from the NKQ in stage I. The analysis of variance for randomized trials (ANOVA) was used to verify the differences in level of nutrition knowledge among economic classes. Data stratified by sex or intervention group were compared in the two stages using the non-parametric Wilcoxon test. The Chi-square test was performed to compare the proportion of adolescents who reported changing their food choices in stage 2 , according to intervention group. A five percent significance level was adopted $(p<0.05)$.

\section{RESULTS}

The PI group was comprised of 34 individuals (50\% girls and 50\% boys) who practiced volleyball and basketball. The Bl group included 24 adolescents (42\% girls and $58 \%$ boys) who practiced indoor soccer and handball. Mean ages (SD), according to sex, were: in PI group girls were I3.6 (0.7) and boys I $4.0(0.7)$ years old $(p=0.07)$ and in BI group girls were $13.2(0.8)$ and boys $14.0(0.8)$ years old $(p=0.02)$. Adolescents' age and anthropometric characteristics according to intervention group are shown in Table I. The BMI and \%BF did not differ significantly between groups. In addition, $85 \%$ of $\mathrm{Pl}$ adolescents and $88 \%$ of $\mathrm{BI}$ adolescents were categorized by the BMI as normal, $12 \%$ of both groups were overweight or obese, and $3 \%$ of the PI group were underweight class I. 
Table I. Age, level of education and body composition of adolescents of sports clubs, according to type of intervention. Brasília, Brazil

\begin{tabular}{|c|c|c|c|}
\hline & \multicolumn{2}{|c|}{ Type of intervention } & \multirow{2}{*}{$\begin{array}{c}\text { Total } \\
(n=58)\end{array}$} \\
\hline & Pyramid $(n=34)$ & Broad $(n=24)$ & \\
\hline & Mean (SD) & Mean (SD) & Mean (SD) \\
\hline Age (years) & |3.8(0.7|) & $13.7(0.87)$ & 13.7 (0.77) \\
\hline Level of education (years) & $6.06(0.85)$ & $5.88(1.23)$ & $5.98(1.02)$ \\
\hline Weight (kg) & 61.I (15.26)* & $53.6(8.67)$ & $57.9(13.37)$ \\
\hline Height (cm) & $170.4(9.86)^{*}$ & $162.3(7.10)$ & |67.| (9.62) \\
\hline $\mathrm{BMI}\left(\mathrm{kg} / \mathrm{m}^{2}\right)$ & $20.9(4.32)$ & $20.3(2.44)$ & $20.7(3.65)$ \\
\hline $\mathrm{BF}(\%)$ & $20.0(6.76)$ & $21.1(8.20)$ & $20.5(7.34)$ \\
\hline
\end{tabular}

$\mathrm{SD}$, Standard deviation; BMI, Body mass index; \%BF, Percentage of body fat; *p $<0.05$, significant difference between intervention groups.

The distribution of adolescents per school year was as follows: $21 \%$ were enrolled in the $6^{\text {th }}$ year, $33 \%$ were in the $7^{\text {th }}$ year, and $38 \%$ were in the $8^{\text {th }}$ year of elementary school. The majority (85\%) of adolescents reported signs of sexual maturation; of these, $65 \%$ belonged to the PI group and 35\% to the BI group. The $\mathrm{PI}$ group was comprised of slightly older individuals and a higher percentage of girls, factors that influenced the presence of sexual maturation.

There were no significant differences in economic classification or level of education between intervention groups, or in the duration and frequency of physical activities and sedentary activities (TABLE 2).

Table 2. Characteristics of time spent on physical activities and sedentary activities by adolescents from sports clubs and schools, according to type of intervention. Brasília, Brazil

\begin{tabular}{lcc}
\hline & \multicolumn{2}{c}{ Type of intervention } \\
\cline { 2 - 3 } Activities & Pyramid $(\mathrm{n}=34)$ & Broad $(\mathrm{n}=24)$ \\
\cline { 2 - 3 } & Mean (SD) & Mean (SD) \\
\hline Main PA (hours of training/day) & $1.61(0.53)$ & $1.72(0.76)$ \\
Main PA (times/week) & $2.56(0.50)$ & $2.67(0.48)$ \\
Total main PA (hours/week) & $4.04(1.28)$ & $4.41(1.85)$ \\
Total PA (main PA + other PAs) & $6.68(3.82)$ & $8.09(4.90)$ \\
(hours/week) & $4.51(1.89)$ & $4.38(2.34)$ \\
Sedentary activities ${ }^{\text {a }}$ (hours/day) &
\end{tabular}

SD, Standard deviation; PA, Physical activity; ${ }^{a}$ TV + DVD + computer. 
The mean PAL (SD) of adolescents from the PI group was I.4I (0. I 2) and of the BI group was I.52 (0.20), with $p<0.05$. However, both groups were categorized as low active by the mean PAL.

Adolescents' food intake was assessed according to the number of servings recommended by the Food Pyramid Adapted to Physically Active Adolescents. The majority of adolescents had an intake lower than the number of servings of fruits (83\% of adolescents), vegetables (98\%), and legumes (72\%). Also, most of the adolescents reported consuming a number of servings higher than the recommended for meat and eggs (71\% of adolescents), sweets and snack foods (98\%) and fats (69\%). The prevalence of adolescents with adequate intake was 52\% for the bread, cereals, tubers and roots group (carbohydrates), and $45 \%$ for milk and dairy products group. Even so, $43 \%$ of adolescents consumed less than the recommended intake for carbohydrates and $48 \%$ for milk and dairy groups.

When separated into groups per type of intervention, the proportion of intake remained below the value recommended by the Adapted Food Pyramid for fruits (76\% and $92 \%$ ), vegetables (97\% and $100 \%$ ), legumes ( $82 \%$ and $58 \% ; p<0.05$ ) and milk and dairy products (38\% and $63 \%$ of adolescents in the $\mathrm{PI}$ and $\mathrm{BI}$ groups, respectively). Intake remained higher than the recommended values for meat and eggs (71\% and $71 \%)$, sweets and snack foods (97\% and 100\%) and fats (74\% and $63 \%$ of adolescents in the $\mathrm{PI}$ and $\mathrm{BI}$ groups, respectively). The intake of the breads, cereals, tubers and roots group was the same as that of the food pyramid for $50 \%$ and $54 \%$ of adolescents in the $\mathrm{PI}$ and $\mathrm{BI}$ groups, respectively. There was a significant difference $(p<0.05)$ in the adequate intake of milk and dairy products, with the majority of adolescents (53\%) in the PI group and only $33 \%$ of those in the $\mathrm{BI}$ group consuming the recommended amount.

The initial nutrition knowledge among adolescents, assessed in stage I, did not vary significantly according to social class, level of education, BMI, or intervention group. However, when categorized by sex, the mean (SD) of the total score, and that of the specific question about distribution of groups in the Food Pyramid of boys $(60.4 \pm 18.3$ and $28.8 \pm 17.5$, respectively) were significantly higher $(p<0.05)$ than those of girls (50.4 14.5 and 20.2 \pm 10.3 ).

Boys and girls had significant improvements in the mean score (SD) of total nutrition knowledge in stage 2 (girls: $67.8 \pm 19.1$, p < 0.00 I; boys: 70.3 \pm 20.8 , $p<0.05)$. In stage 2 , the increase in the mean score (SD) of the specific question about distribution of food groups in the Food Pyramid was significant for girls $(36.9 \pm 17.5, p<0.00 \mathrm{I})$ and not significant for boys $(37.4 \pm 20.5 ; p=0.06)$.

In stage 2 , a total of five adolescents (8.6\%) were not contacted, two in the PI group and three in the BI group. In this stage, adolescents of both groups had 
significant improvements in the mean scores of the NKQ, the minimum score obtained and the scores obtained from the specific question about distribution of food groups in the Food Pyramid. For all parameters, there were no significant differences in improvements between groups, i.e. the $\mathrm{PI}$ and $\mathrm{BI}$ groups showed better scores in stage 2, regardless of the type of intervention (Figure 2).

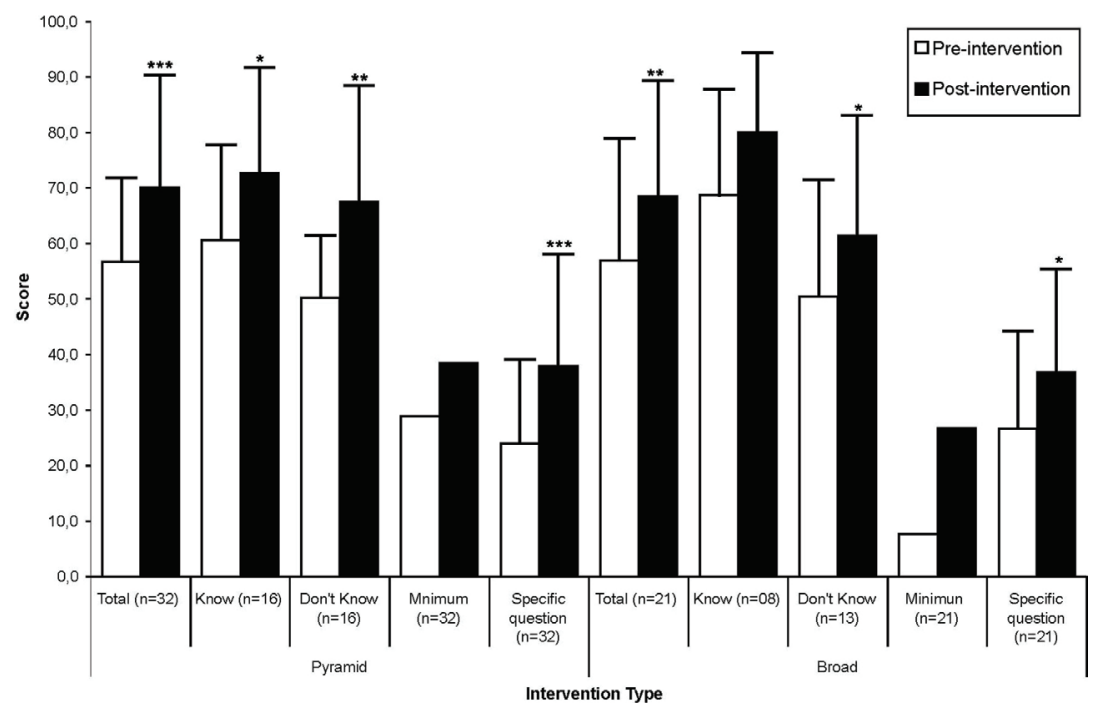

Figure 2. Mean score (standard deviation) obtained in the nutritional knowledge questionnaire (NKQ), according to type of intervention (Pyramid / Broad) and research phase (Pre / Post intervention).

Label: Data in columns refer to: Total $=$ mean score on the questionnaire; Know $=$ mean score of adolescents that declared to know the pyramid food guide previously; Don't Know = mean score of adolescents that declared to not know the pyramid food guide previously; Minimum = lowest score on the questionnaire; Specific question = mean score on the specific question about the distribution of food groups on the pyramid food guide. Significant statistical differences ***, $p<0.001$; **, $p<0.01$; *, $p<0.05$ by Wilcoxon test between stages I and 2 .

The adolescents in the PI group who reported knowing the pyramid-shaped food guide before the intervention (stage I) and those in the $\mathrm{Pl}$ and $\mathrm{BI}$ who reported not knowing it significantly increased the total number of points obtained from the NKQ after the intervention (FIGURE 2). The only exception was the BI group, who affirmed that they knew the food pyramid guide, with the increase in the score in stage 2 not reaching significance in the Wilcoxon test. These results suggest that, regardless of previous contact with the Food Pyramid guide, there was an improvement in nutrition knowledge with the interventions. In addition, no significant correlation was observed between nutrition knowledge score in stage 2 and PAL $(r=-0.02$; $p=0.88)$ and with the number of hours of sedentary activity $(r=0.20 ; p=0.16)$. 


\section{DISCUSSION}

The study sample reflects a profile of Brazilian adolescents who are pubescent, have normal weight, and are engaged in sports training, although with a high level of sedentary activities. Several studies conducted with physically active adolescents (DE SOUSA et al., 2008; NOGUEIRA; DA COSTA, 2009; DOWDA et al., 200 I; EISENMANN; BARTEE; WANG, 2002; GARRIDO; WEBSTER; CHAMORRO, 2007; IGLESIAS-GUTIÉRREZ et al., 2008) have indicated a higher prevalence of normal BMI. There were significant differences in weight and height between groups, which probably reflect the distinct types of sports practiced by these groups. The PI group included adolescents who practiced basketball and volleyball, sports in which height is the usual selection parameter. In addition, the BI group included more boys than girls, so it was less homogeneous with respect to gender than the PI group. Girls' initial knowledge was lower than boys, which may be regarded as a potential disadvantage for the PI group.

Although the total number of hours spent on physical activities was slightly higher in the $\mathrm{BI}$ group than the PI group, adolescents from both groups met the recommendations of 60 minutes of daily moderate to vigorous physical activity on most days of the week and were considered as physically active (INSTITUTE OF MEDICINE, 2002; WHO, 2004; AMERICAN ACADEMY OF PEDIATRICS et al., 2006). In addition, the mean values found were in agreement with those of other studies conducted with physically active individuals that reported approximately between 5 and 12 weekly hours of physical activities (GARRIDO; WEBSTER; CHAMORRO, 2007; DE SOUSA et al., 2008; IGLESIAS-GUTIÉRREZ et al., 2008; NOGUEIRA; DA COSTA, 2009).

In contrast, the mean number of hours spent on sedentary activities (hours of television, DVD and computer) per day by adolescents in the present study was higher than the recommendation of up to two hours per day of electronic media for entertainment (WHO, 2004; AMERICAN ACADEMY OF PEDIATRICS et al., 2006), despite being in agreement with other studies conducted with children and adolescents (DOWDA et al., 200 I; EISENMANN; BARTEE; WANG, 2002). This fact helps to explain why the mean PAL was categorized as low active (INSTITUTE OF MEDICINE, 2002). None of the previously mentioned studies reported PAL values for comparison.

Based on the data on low intake of servings of the fruits, vegetables and legumes groups and high intake of the fats, sweets and snack foods group and meat and eggs group, this study showed that there is still room and the need for information about diet and nutrition to be passed on to this population. Furthermore, the habits reported 
by these adolescents reflect patterns of unhealthy eating habits, also found among adolescents of various other countries (D'ALESSANDRO et al., 2007; GARRIDO; WEBSTER; CHAMORRO, 2007; IGLESIAS-GUTIÉRREZ et al., 2008; DA COSTA et al., 20 I 2). The maintenance of diets with little variety of foods and the fact that regular physical activity practice increases nutritional requirements of energy and certain nutrients (INSTITUTE OF MEDICINE, 2002; AMERICAN HEART ASSOCIATION, 2006) could mean that adolescents engaged in sports are at a higher risk of developing nutritional deficiencies.

In addition, the present study showed that adolescents' knowledge about diet and nutrition is average (mean of 55 points) and is not influenced by PAL, BMI and economic class. There were also other studies that did not find significant differences in nutrition knowledge between obese and normal children and adolescents categorized by the BMI (THAKUR; D'AMICO, 1999; REINEHR et al., 200 I).

When analyzed by sex, the mean score obtained from the NKQ pointed to boys showing a better result. The fact that boys had a higher mean age and were one school year ahead of girls on average could help to explain these initial differences. Studies assessing the gain in nutrition knowledge by adolescents did not perform an assessment according to sex (THAKUR; D'AMICO, 1999; REINEHR et al., 200 I; TRICHES; GIUGLIANI, 2005; WATSON et al., 2009), although one study pointed to girls having better nutrition knowledge than boys, as they were more involved with food preparation and cared more for their body image in general (TURCONI et al., 2008). However, the initial differences were disregarded after the intervention, when boys and girls obtained similar mean total numbers of points from the NKQ. There was a greater improvement in knowledge among girls, which could have been due to their lower initial nutrition knowledge.

Finally, the present study showed that adolescents understand the food pyramid guide and that the Food Pyramid Adapted to Physically Active Adolescents is an efficient diet and nutrition education tool for this group. Moreover, we observed that previous contact or not with similar food guides did not influence the efficiency of this tool in the dissemination of information about nutrition to adolescents engaged in sports. The increase in nutrition knowledge after the interventions can be observed through the significant increases in the results of the following three variables: total number of points in the NKQ, minimum score in the NKQ, and score of the specific question about understanding of the food pyramid. All variables improved, regardless of whether the group did or did not receive an explanatory lecture prior to the educational material, which indicates the self-explanatory nature of the educational tool. It is important to consider that the short time between assessments may have helped the positive results related to the increase in scores between stages $\mid$ and 2 . 
However, the self-explanatory capacity, which is independent of the time duration between exposure and evaluation of the tool, was proven.

The present study did not investigate the change in eating habits resulting from the increase in adolescents' nutrition knowledge. This limitation was due to the short space of time between interviews. However, the increase in nutrition knowledge is viewed as a key factor to change eating habits (PÉREZ-RODRIGO; ARANCETA, 200 I; WORSLEY, 2002; TRICHES; GIUGLIANI, 2005; PRELIP, 20 I I). In this context, the adapted food pyramid can be used as a visual tool to facilitate understanding and the maintenance of a healthy diet (PHILIPPI et al., I999; GONZÁLEZ-GROSS et al., 2008; METTLER; MANNHART; COLOMBANI, 2009). However, nutrition knowledge does not necessarily influence food choices and preferences. The increase in nutrition knowledge causes the understanding of healthier food choices, which is an important determinant of attitudes, although eating habits are influenced by other basic concepts inherent in individuals that are not affected by nutrition knowledge (WORSLEY, 2002; CRITES; AIKMAN, 2005). These other factors that influence eating habits need to be better understood for the development of nutrition interventions that can improve these habits among adolescents (STORY; NEUMARK-SZTAINER; FRENCH, 2002; CRITES; AIKMAN, 2005).

Following recommendations that accessible and effective tools should be used in health promotion programs including eating habits and knowledge (PHILIPPI et al., 1999; CRITES; AIKMAN, 2005; AMERICAN HEART ASSOCIATION, 2006; GONZÁLEZ-GROSS et al., 2008; METTLER; MANNHART; COLOMBANI, 2009; UNITED STATE, 20I2) the present study proposed the use of the Food Pyramid Adapted to Physically Active Adolescents as a nutrition education tool for this group. This tool was found to be appropriate, as it is accessible and effective in the dissemination of information about nutrition among this population. Efforts to promote healthy lifestyle among adolescents are needed and should place greater emphasis on combining physical activity with a balanced diet, since sport activities may increase nutritional needs.

\section{CONCLUSION}

The Food Pyramid Adapted to Physically Active Adolescents is an educational tool that can be understood in a self-explanatory way by adolescents, regardless of sex, previous nutrition knowledge, BMI and PAL. Thus, health professionals, sports coaches and physical education teachers can use this Food Pyramid to inform physically active adolescents about food choices and to help them to improve nutritional knowledge. Changes in eating habits made through the use of the Adapted Food 
Pyramid must be analyzed in future studies, as nutrition knowledge acquisition is only one of the essential steps in this process.

\section{A pirâmide alimentar adaptada para adolescentes fisicamente ativos como ferramenta de educação nutricional}

RESUMO: O estudo avaliou a compreensão da Pirâmide Alimentar Adaptada para Adolescentes Fisicamente Ativos como ferramenta educacional para melhorar o conhecimento em nutrição. Adolescentes que treinam um esporte responderam questionário de conhecimento em nutrição antes e depois da intervenção. O grupo de intervenção pirâmide recebeu o material educacional impresso e o grupo intervenção ampla recebeu o material impresso seguido de palestra. O conhecimento nutricional inicial foi mediano (59,9 \pm 18 pontos), com aumento ( $p<0,001)$ após a intervenção (69,1 \pm 20 pontos), sem diferença significativa por tipo de intervenção. O conhecimento de adolescentes em nutrição melhorou, mesmo com o uso da Pirâmide Alimentar sozinha, indicando seu uso para promover o conhecimento nutricional. PALAVRAS-CHAVE: Adolescência; esportes; hábitos alimentares; grupos de alimentos.

\section{La pirámide alimentar adaptada para adolescentes físicamente activos como herramienta de educación en nutrición}

RESUMEN: Lo estudio evaluó la comprensión de la pirámide de alimentos adaptado a los adolescentes físicamente activos como una herramienta educativa para mejorar el conocimiento de la nutrición. Los adolescentes que participan en el entrenamiento deportivo respondió a un cuestionario de conocimientos sobre nutrición antes y después de la intervención. El grupo de intervención la pirámide recibió material educativo impreso, y la intervención amplia recibió el material impreso seguido por una conferencia. Como resultados, la media de conocimientos sobre nutrición inicial era (59,9 \pm 18 puntos), con aumento ( $p<0,001)$ después de la intervención $(69,1 \pm 20$ puntos), sin diferencia significativa entre las intervenciones. El conocimiento de Adolescentes sobre nutrición foie mejorada, incluso con el uso de la pirámide de alimentos solo, lo que indica su uso para promover el conocimiento nutricional.

PALABRAS CLAVE: Adolescencia; deportes; hábitos alimentarios; grupos de alimentos.

\section{REFERENCES}

ALBERGA, A. S. et al. Overweight and obese teenagers: why is adolescence a critical period? Pediatric Obesity, Oxford, v. 7, n. 4, p. 261-273, aug. 012.

ALLISON, K. R.et al. The decline in physical activity among adolescent students: a cross-national comparison. Canadian Journal of Public Health, Ottawa, v. 98, n. 2, p. 97-100, mar./apr. 2007.

AMERICAN ACADEMY OF PEDIATRICS. Active healthy living: prevention of childhood obesity through increased physical activity. Pediatrics, Springfield, v. I I7, p. 1834- I842, may 2006. 
AMERICAN HEART ASSOCIATION. Scientific statement: diet and lifestyle recommendations revision 2006. Circulation, Baltimore, v. I |4, n. I, p. 82-96, july 2006.

ASSOCIAÇÃO BRASILEIRA DE EMPRESAS DE PESQUISA (ABEP). 2003. Disponível em: <http://www.abep.org/codigosguias/ABEP_CCEB.pdf> Acesso em: 17 dez. 2009.

BOILEAU, R. A.; LOHMAN, T. G.; SLAUGHTER, M. H. Exercise and body composition of children and youth. Scandinavian Journal of Sports Science, v. 7, n. I, p. 17-27, 1985.

COLE, T. J. et al. Establishing a standard definition for child overweight and obesity worldwide: international survey. British Medical Journal, London, v. 320, p. I240- I247, may 2000.

COLE, T. J.; KATHERINE, M. F. Body mass index cut offs to define thinness in children and adolescents: international survey. British Medical Journal, London, v. 335, p. 194-202, july 2007.

CRITES, S. L.; AIKMAN, S. N. Impact of nutrition knowledge on food evaluations. European Journal of Clinical Nutrition, London, v. 59, n. 10, p. I | 9 |-1200, oct. 2005.

D'ALESSANDRO, C. et al. Profiling the diet and body composition of subelite adolescent rhythmic gymnasts. Pediatric Exercise Science, Champaign, v. 19, n. 2, p. 21 5-227, may 2007.

DA COSTA, T. H. et al. Avaliação nutricional de atletas adolescentes do Distrito Federal. Disponível em: <http://www.unb.br/fs/adolescente/pira_internet.pdf.> Accesso em: I 6 jan. 2012.

DE SOUSA, E. F. et al. Assessment of nutrient and water intake among adolescents from sports federations in the Federal District, Brazil. British Journal of Nutrition, Cambridge, v. 99, n. 6, p. 1275-1283, june 2008.

DOWDA, M. et al. Environmental influences, physical activity, and weight status in 8- to 16-year-olds. Archives of Pediatrics \& Adolescent Medicine, Chicago, v. 155, n. 6, p.7 | 1-7 |7, june 2001 .

DWYER, J. et al. Adolescents' eating patterns influence their nutrient intakes. Journal of the American Dietetic Association, New York, v. I0I, n. 7, p. 798-802, july 2001.

EISENMANN, J. C.; BARTEE, R. T.; WANG, M. Q. Physical activity, TV viewing, and weight in U.S. youth: 1999 Youth Risk Behavior Survey. Obesity Research, Baton Rouge, v. I0, n. 5, p. 379-385, may 2002.

FLECK, S. J.; KRAEMER, W. J. Designing resistance training programs. $3^{\text {rd }}$ ed. Champaign: Human Kinetics, 2004.

FOOD AND AGRICULTURE ORGANIZATION (FAO). Expert consultation: human energy requirements. FAO food and nutrition technical report series I. Rome, 200 I.

GARRIDO, G.; WEBSTER, A. L.; CHAMORRO, M. Nutritional adequacy of different menu settings in elite spanish adolescent soccer players. International Journal of Sport Nutrition and Exercise Metabolism, Champaign, v. 17, n. 5, p. 421-432, oct. 2007. 
GONZÁLEZ-GROSS, M. et al. The "healthy lifestyle guide pyramid" for children and adolescents. Nutritíon Hospitalaria, Madrid, v. 23, n. 2, p. I59-168, mar./apr. 2008.

IGLESIAS-GUTIÉRREZ, E. et al. Food preferences do not influence adolescent high-level athletes' dietary intake. Appetite, London, v. 50, n. 2-3, p. 536-543, mar./may 2008.

INSTITUTE OF MEDICINE. Dietary reference intakes for energy, carbohydrate, fiber, fat, fatty acids, cholesterol, protein, and amino acids (Macronutrients). Washington: National Academy, 2002.

INTERNATIONAL PHYSICAL ACTIVITY QUESTIONNAIRE (IPAQ): short format version. Disponível em: <http://www.ipaq.ki.se/downloads.htm>. Accesso em: 17 dec. 2009.

LIMA, E. D.; MONTEIRO, E. A.; PAES, A. Educação nutricional na escola do primeiro grau em Pernambuco (Brasil): diagnóstico. Revista de Saúde Pública, São Paulo, v. 19, n. 6, p. 508-520, dez. 1985.

LOHMAN, T. G.; ROCHE, A. F; MARTORELL, R. Anthropometric standardization reference manual. Champaign: Human Kinetics Books, 1988.

METTLER, S.; MANNHART C.; COLOMBANI, P. C. Development and validation of a food pyramid for swiss athletes. International Journal of Sport Nutrition and Exercise Metabolism, Champaign, v. 19, n. 5, p. 504-518, oct. 2009.

NOGUEIRA, J. A.; DA COSTA, T. H. Gender differences in physical activity, sedentary behavior and its relation to body composition in active Brazilian adolescents. Journal of Physical Activity \& Health, Champaign, v. 6, n. I, p. 93-98, jan. 2009.

NOGUEIRA, J. A.; DA COSTA, T. H. Nutrient intake and eating habits of triathletes on a brazilian diet. International Journal of Sport Nutrition and Exercise Metabolism, Champaign, v.|4, n. 6, p. 684-697, dec. 2004.

PÉREZ-RODRIGO, C.; ARANCETA, J. School-based nutrition education: lessons learned and new perspectives. Public Health Nutrition, Wallingford, v. 4, n. IA, p. I3 I-139, feb. 200 I.

PHILIPPI, S. T. et al. Pirâmide alimentar adaptada: guia para escolha dos alimentos. Revista de Nutrição, Campinas, v. 12, n. I, p. 65-80, jan./apr. 1999.

PRELIP, M. et al. Effects of a school-based nutrition program diffused throughout a large urban community on attitudes, beliefs, and behaviors related to fruit and vegetable consumption. Journal of School Health, Hoboken, v. 8I, n. 9, p. 520-529, sept. 201 I.

REES, J. M. et al. Improving the nutritional health of adolescents -position statement- society for adolescent medicine. Journal of Adolescent Health, New York, v. 24, n. 6, p. 46I-462, june 1999.

REINEHR, T. et al. Nutritional knowledge of obese and nonobese children. Journal of Pediatric Gastroenterology and Nutrition, Philadelphia, v. 33, n. 3, p. 35I, sept. 2001. 
SIRI, W. E. The gross composition of the body. Advances in Biological and Medical Physics, New York, v. 4, p. 239-280, jan. 1956.

STORY, M.; NEUMARK-SZTAINER, D.; FRENCH, S. Individual and environmental influences on adolescent eating behaviors. Journal of the American Dietetic Association, Chicago, v. 102 , n. S3, p. S40-S5I, mar. 2002.

THAKUR, N.; D'AMICO, F. Relationship of nutrition knowledge and obesity in adolescence. Family Medicine, Kansas, v. 31 , n. 2, p. 122-127, feb. 1999.

TRICHES, R. Z.; GIUGLIANI, E. R. Obesidade, práticas alimentares e conhecimentos de nutrição em escolares. Revista de Saúde Pública, São Paulo, v. 39, n. 4, p. 54 I-547, aug. 2005

TURCONI, G. et al. Eating habits and behaviors, physical activity, nutritional and food safety knowledge and beliefs in an adolescent Italian population. Journal of the American College of Nutrition, New York, v. 27, n. I, p. 3 I-43, feb. 2008.

UNITED STATE. DEPARTMENT OF AGRICULTURE (USDA). Choose my plate. Disponível em: <http://www.choosemyplate.gov/>. Accesso: 16 jan. 2012.

WATSON, L. C. et al. Evaluation of the nutrition knowledge, attitudes, and food consumption behaviors of high school students before and after completion of a nutrition course. Family and Consumer Sciences Research Journal, Thousand Oaks, v. 37, n. 4, p. 523-534, jul. 2009.

WORLD HEALTH ORGANIZATION (WHO). Global strategy on diet, physical activity and health: fifty-seventh World Health Assembly (WHA 57.17), may 2004. Disponível em: <www.who.int/dietphysicalactivity/strategy/eb I I344/strategy_english_web.pdf >. Accesso em: 12 dec. 2009.

WORSLEY, A. Nutrition knowledge and food consumption: can nutrition knowledge change food behavior? Asia Pacific Journal of Clinical Nutrition, Melbourne, v. I I , s. 3, p. S579-585, jan. 2002.

Recebido em: 30 set. 2012 Aprovado em: 21 maio 2013 Endereço para correspondência: Júlia Aparecida Devidé Nogueira Faculdade de Educação Física, Campus Universitário Darcy Ribeiro Universidade de Brasília; Brasília-DF

CEP: 70910-900 